\title{
Estrutura e reactividade molecular *
}

A.J.C. Varandas

Presidente da Comissão Científica

\section{Sr. Vice-Reitor **}

Sr. Presidente da Sociedade Portuguesa de Química

Sr. Secretário Geral da Sociedade Portuguesa de Química

Sr. Presidente do Departamento de Química

Senhoras e Senhores,

Reunem-se uma vez mais em Coimbra, sob a égide da Sociedade Portuguesa de Química, os químicos portugueses. Participam também nesta reunião químicos de outros países dos quais será justo realçar, pela significativa presença, os do pais vizinho, a Espanha. Trata-se do IX Encontro Anual da Sociedade Portuguesa de Química, este ano tendo como tema central a Estrutura e Reactividade Molecular. Tentarei, em breves palavras, indicar as razoes que levaram a Comissão Cientifíca a escolher este tema. Um dos principais objectivos da Químicả é o estudo das transformaçôes moleculares, que ocorrem das colisð̋es das moléculas com outras moléculas, da sua interacção com a luz, ou mesmo delas próprias. Em sintese, é o estudo da reactividade química quer em fase gasosa diluída, Dinâmica Química, quer em fase condensada, este um dos tópicos centrais da Cinética Química convencional. Naturalmente, como em qualquer ciência da Natureza com firme fundamentação teórica, o químico deve procurar uma reacionalização dos parâmetros cinéticos macroscópicos em termos dos parâmetros cinéticos microscópicos respeitantes a reacçōes elementares a nivel molecular, e estes, por sua vez, em termos dos parâmetros estruturais das moléculas, que se podem obter da espectroscopia e da termodinâmica. Teoria e experiência devem pois complementar-se na aventura de desvendar os segredos infinitamente complexo e inumeráveis do Cosmos.

Cabe à Mecânica Quântica, suporte matemático da Química Quântica, satisfazer as premissas de uma teoria que permita racionalizar $o$ conhecimento actual do mundo microscópico e fazer previsðes sugerindo novas experiências. Contudo, em Química, a maioria das observaçðes experimentais são obtidas à escala macroscópica, pelo que os valores medidos reflectem médias temporais relativas a um número de espécies moleculares da ordem de grandeza do número de Avogadro e um periodo de tempo igual àquele que decorreu no acto da medição experimental. Compete à Mecânica Estatística a conexão entre estas duas escalas da realidade química, estabelecendo os princípios e formalismo matemáticos necessários ao cálculo das propriedades macroscópicas a partir dos correspondentes parâmetros microscópicos. A Mecância Quântica e a Mecânica Estatistica constituem, pois, a coluna dorsal da teoria mais geral da Química, à luz da qual se poderão explicar e prever os resultados experimentais, bem como formular conceitos a partir dos quais novos conceitos emergirão.

Seria grave omitir aqui uma referência, breve por necessidade, ao papel desempenhado pelo computador. De facto, embora os fundamentos da Mecânica Quântica datem do primeiro quartel deste século, foi somente com o desenvolvimento da Química Computacional nas duas últimas décadas, que grande número dos aspectos teóricos ganhou um plano de maior evidência, porventura de interesse prático imediato. É hoje aceite atribuir às experiências computacionais um papel de importância semelhante, na sua complementaridade, ao das experiências convencionạis de laboratório. Numa altura em que a Universidade de Coimbra pretende usufruir dos beneficios da Terceira Revolução Industrial, definindo as suas necessidades informáticas para o futuro próximo, aliás no segui- mento de passoas já dados pelas Universidades de países em fase mais avançada de desenvolvimento, será oportuno alertar para o papel essencial do computador na obtenção dos resultados que serão apresentados por alguns dos nossos oradores convidados, especialistas de grande prestígio internacional.

Em relação ao cálculo automático, parece-me ainda oportuno recordar aqui alguns anseios que manifestei, em 1980, aquando do $3 .^{\circ}$ Encontro Anual da Sociedade Portuguesa de Química e que, naturalmente, assumem agora uma maior urgência. Referia-me, então, à importância de equipar o nosso Pais com uma rede informática moderna, que cerebralizada por um supercomputador central, a nivel nacional, pudesse servir de apoio às necessidades crescentes de cálculo numérico pesado, tanto por parte da Universidade como por parte de outras instituiçðes públicas e, talvez, mesmo privadas. Com as Universidade equipadas com computadores autónomos, e também terminais desta superestrutura, penso que teríamos dado um passo qualitativo neste domínio. Aliás, uma tal linha de acção conduziria, de modo natural, ao estabelecimento de um centro de investigação interdisciplinar em que o cálculo numérico fosse a ferramenta preponderante. Ficam aqui, pois, de novo, em 1986, os meus anseios na esperança de que alguém competente os possa levar em atenção.

Concluo, recolhendo nesta transparência (Figura 1) alguns dos temas a que me referi indicando também

\footnotetext{
- Palavras proferidas na cerimónia do IX Encontro Anual da Sociedade Portuguesa de Quimica, realizado de 2 a 4 de Junho de 1986, em Coimbra.

* Em representaçå̃o do Sr. Reitor da Universidade de Coimbra.

*** Em representação do Sr. Presidente do Conselho Cientifico da Faculdade de Ciências e Tecnologia da Universidade de Coimbra.
} 


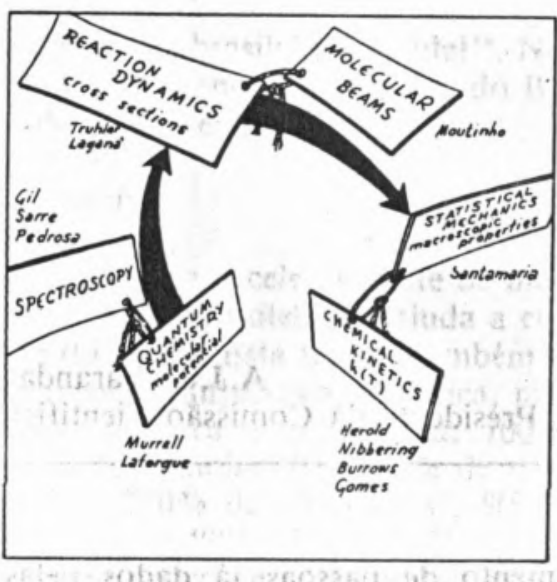

os nomes dos nossos oradores convidados. Devo salientar que muitos deles têm contribuído nas suas pesquisas para o desenvolvimento de mais do que um dos domínios apre- sentados nesta transparência. Pareceu-me oportuno, no entanto, situá-los, repito sem grandes compromissos de rigor, nos temas que melhor se coadunam com os conteúdos das suas conferências.

Espero ter apresentado algumas razð̄es significativas que levaram a Comissão Científica a optar pelo tema deste IX Encontro Anual da Sociedade Portuguesa de Química. Estou certo de que o esforço dispendido pela Comissão Organizadora e o brilhantismo dos oradores convidados nos fará apreciar no futuro esta área da Química com redobrado interesse.

Façamos como na história Gaulesa (Figura 2): estejamos atentos aos resultados novos, que sem dúvida

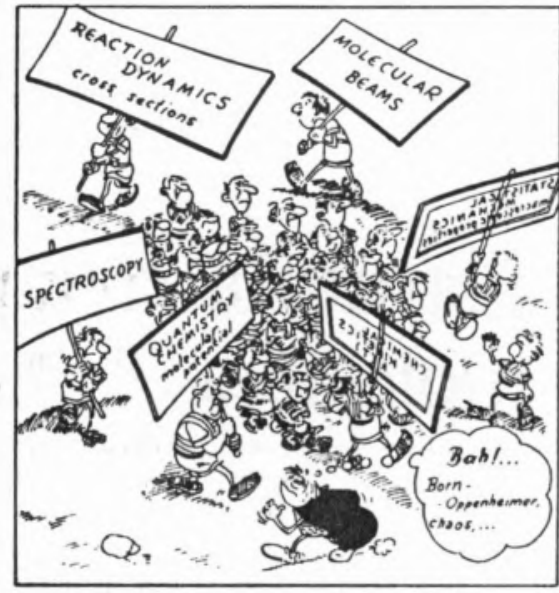

irão enriquecer o património científico, e às críticas naturais, e até necessárias, para um caminhar firme e decisivo. 